\title{
ECONOMICS
}

\section{ENERGY INTENSITY AND ITS DETERMINANTS IN CHINA'S REGIONAL ECONOMIES}

\author{
by
}

\author{
Yanrui Wu
}

Business School

University of Western Australia 


\title{
ENERGY INTENSITY AND ITS DETERMINANTS IN CHINA'S
}

\section{REGIONAL ECONOMIES*}

\author{
Yanrui $\mathrm{Wu}$ \\ Economics Program (M251) \\ UWA Business School \\ University of Western Australia \\ WA 6009, Australia \\ yanrui.wu@uwa.edu.au \\ 61864883964 (tel) \\ 61864881016 (fax)
}

Forthcoming in Energy Policy

DISCUSSION PAPER 11.25

* Work on this paper was supported by an ARC Discovery Project grant (DP1092913). I thank James Cheong, Dahai Fu and Nickolas Sin for their excellent research assistance, and Professor Bin Wang of Jinan University for assistance with data collection. I also acknowledge the participants of ACESA2010 (La Trobe University, 2010) and the $12^{\text {th }}$ EAEA convention (Ewha Womans University, 2010), Enjiang Cheng, Chunbo Ma, and Rachel C. Reyes for helpful comments and suggestions. 


\begin{abstract}
This paper contributes to the existing literature as well as policy debates by examining energy intensity and its determinants in China's regional economies. The analysis is based on a comprehensive database of China's regional energy balance constructed for this project. Through its focus on regional China, this study extends the existing literature which mainly covers nationwide studies. It is found in this paper that energy intensity declined substantially in China. The main contributing factor is the improvement in energy efficiency. Changes in the economic structure have so far affected energy intensity modestly. Thus there is considerable scope to reduce energy intensity through the structural transformation of the Chinese economy in the future.
\end{abstract}

Key words Energy intensity, energy efficiency, structural change and China JEL codes Q43, R11 and Q48 


\section{Introduction}

Over the past three decades the Chinese economy has indeed achieved impressively high growth. This growth is however associated with deteriorating environmental conditions in the country (World Bank 2001, Wu 2010). With increasing environmental awareness in the society and demand for better quality of life by ordinary citizens, Chinese policy makers are under tremendous pressure to rechart the country's course of growth in the coming decades. A key issue of concern is related to energy consumption which is the main source of pollutants in the air, soil and water. China is now the world's largest energy consumer as well as $\mathrm{CO}_{2}$ emitter. The country's energy consumption pattern will have important implications for the global environment.

So far the literature has focused on forecasting future energy consumption in China particularly at the aggregate level (Crompton and $\mathrm{Wu}$ 2003, IEA 2009). There are a few papers which investigated China's energy intensity (defined as the ratio of energy consumption over output such as GDP). As shown in Table 1, these studies can be broadly divided into several groups, namely, national, regional, sectoral and other studies. First, Garbaccio et al. (1999) and Ma and Stern (2008) adopted different decomposition methods to examine energy intensity at the national level. Second, Huang (1993), Sinton and Levine (1994) and Zhang (2003) represented earlier studies of energy intensity in China's industrial sector in the 1980s and 1990s. Recently Liao et al. (2007) and Zhao et al. (2010) extended earlier studies to sub-sectors at the twodigit level. All sectoral studies followed the decomposition method. Zheng et al. (2011) is an exception which applied regression analysis to investigate the impact of exports on energy intensity in 20 sub-sectors during 1999-2007. 
Table 1 Major Studies of China's Energy Intensity

\begin{tabular}{|c|c|c|}
\hline Authors & Data & Method \\
\hline \multicolumn{3}{|l|}{ National/aggregate level } \\
\hline Garbaccio et al. (1999) & $1987 \& 1992$ & I-O tables/index method \\
\hline Ma and Stern (2008) & $1980-2003$ & LMDI \\
\hline \multicolumn{3}{|l|}{ Sectoral level } \\
\hline Huang (1993) & $1980-88$ & Divisia index/Industry \\
\hline Sinton and Levine (1994) & $1980 \mathrm{~s}$ & Laspeyres index/Industry \\
\hline Zhang (2003) & $1990 \mathrm{~s}$ & IDA/29 sub-sectors \\
\hline Liao et al. (2007) & $1997-2006$ & IDA/36 sub-sectors \\
\hline Zhao et al. (2010) & $1998-2006$ & LMDI/15 sub-sectors \\
\hline Zheng et al. (2011) & $1999-2007$ & Regressions/20 sub-sectors (exports) \\
\hline \multicolumn{3}{|l|}{ Regional } \\
\hline Qi and Luo (2007), & $1995-2002$ & Regressions \\
\hline Li and Wang (2008) & $1995-2005$ & LMDI \\
\hline Ma et al. (2009) & $1995-2004$ & Cost functions \\
\hline Wang and Zhong (2009). & $1995-2006$ & Regressions \\
\hline Yuxiang and Chen 2010 & $1996-2006$ & Regressions/government spending \\
\hline \multicolumn{3}{|l|}{ Other studies } \\
\hline Fisher-Vanden et al. (2004) & 1997-99 & Divisia/regressions (firm level) \\
\hline Golley (2008) & 2005 & Energy requirement (household level) \\
\hline Chai et al. (2009) & 4 years & I-O tables/30 sub-sectors (1992-2004) \\
\hline
\end{tabular}

Source: Author's own compilation.

Note: I-O tables: Input-output tables. LMDI: Logarithmic mean Divisia index. IDA: Index decomposition analysis.

Third, several recent papers employed provincial (regional) data and regression techniques to examine China's energy intensity. For example, Qi and Luo (2007) investigated the relationship between energy intensity and economic growth, Wang and Zhong (2009) explored the effect of regional resource endowment on energy intensity, and Yuxiang and Chen (2010) examined the impact of government expenditure on energy intensity. Furthermore, Ma et al. (2009) investigated the substitutability between fuels and between energy and factor inputs (capital and labour) and Li and Wang (2008) adopted the popular logarithmic mean Divisia index 
(LMDI) approach to understand energy intensity changes across the regions. Finally, several papers are differentiated from the national, sectoral and regional studies just reviewed. Fisher-Vanden et al. (2004) is the first paper with a focus on energy intensity at the firm-level (involving data of 2500 firms and three years 1997-1999). Golley et al. (2008) presented a detailed study of energy requirement and $\mathrm{CO}_{2}$ emissions at household level in urban China. Chai et al. (2009) employed a decomposition method involving the input-output table to explore how various factors affect energy intensity in China.

The present study extends the existing literature in two ways. The analysis is for the first time based on sectoral energy consumption data in the Chinese regions. In addition, it applies regression analyses to examine the determinants of energy intensity and its components at the regional level. It is found in this study that there is considerable regional disparity in energy intensity as well as its trend of movement over time. It is also shown in the empirical analysis that changes in regional energy intensity are mainly affected by energy efficiency changes with hardly any impact from economic structural transformation in the regions. This finding implies the need for urgent policy actions in order to reduce energy intensity through structural changes in China's regional economies in the coming decades. Other factors which are important for the reduction in energy intensity include energy prices and adoption of new technologies in regional economies.

The rest of the paper begins with Section 2 where energy intensity at the national level is briefly discussed. Section 3 then presents a preliminary analysis of energy intensity in the regions. Subsequently, regression analysis in Section 4 is employed to 
investigate the determinants of regional intensity variations. This is followed by further discussions of selected issues in Section 5. The concluding remarks are presented in Section 6.

\section{Energy Intensity in China}

During the period of 1953-2009 the movement of China's energy intensity basically followed an inverted U-shaped curve though total energy consumption increased steadily (Figure 1). Before the country's economic reform program was introduced in 1978, energy intensity fluctuated considerably and its overall trend of changes was upward. It peaked twice in 1960 and 1977, respectively. This course of changes is consistent with the pattern of economic growth before 1978. During that period, the Chinese economy experienced a few ups and downs due to political chaos and poor economic policies. However, during the post-reform decades (1978-2009), energy intensity basically followed a declining trend though there were temporary disruptions in several years, namely, in 1989 and during 2003-2005 when energy intensity was recorded with a minor increase. Thus the "dematerialization" phenomenon was also observed in China as income increases over time (Bernardini and Galli 1993). In international perspectives, China's energy intensity is converging rapidly with major energy consumers in the world (Figure 2). Especially, China seems to follow the similar paths undergone by Japan and South Korea. If the overall trend is maintained, China could even do better than the major economies in terms of energy intensity reduction in the future (refer to the solid line in Figure 2). 


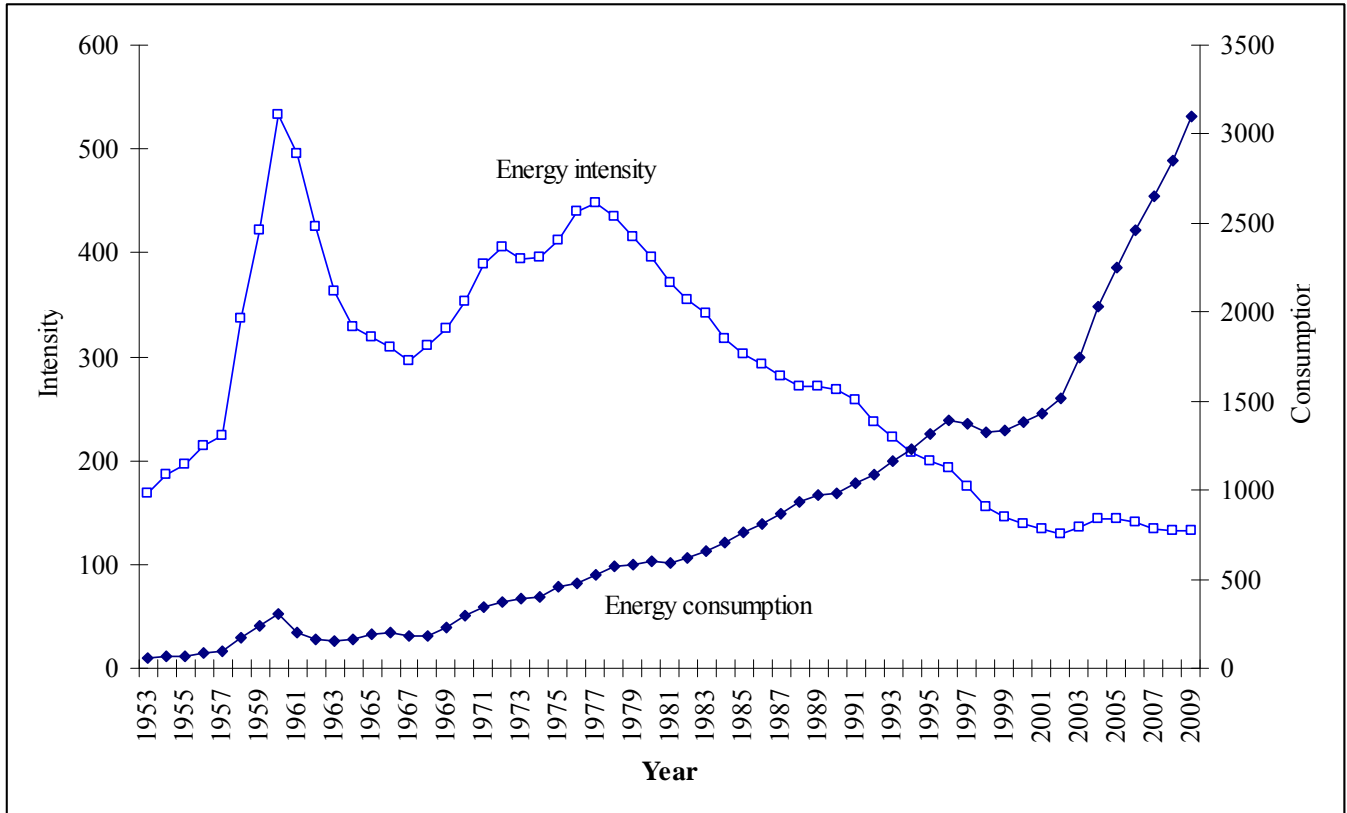

Note: Energy intensity is expressed in kilograms coal equivalent per 1000 yuan in 2000 prices and energy consumption in million tons (MTs) coal equivalent.

Sources: NBS (various issues, 2009 and 2010).

Figure 1 China's Energy intensity 1953-2009

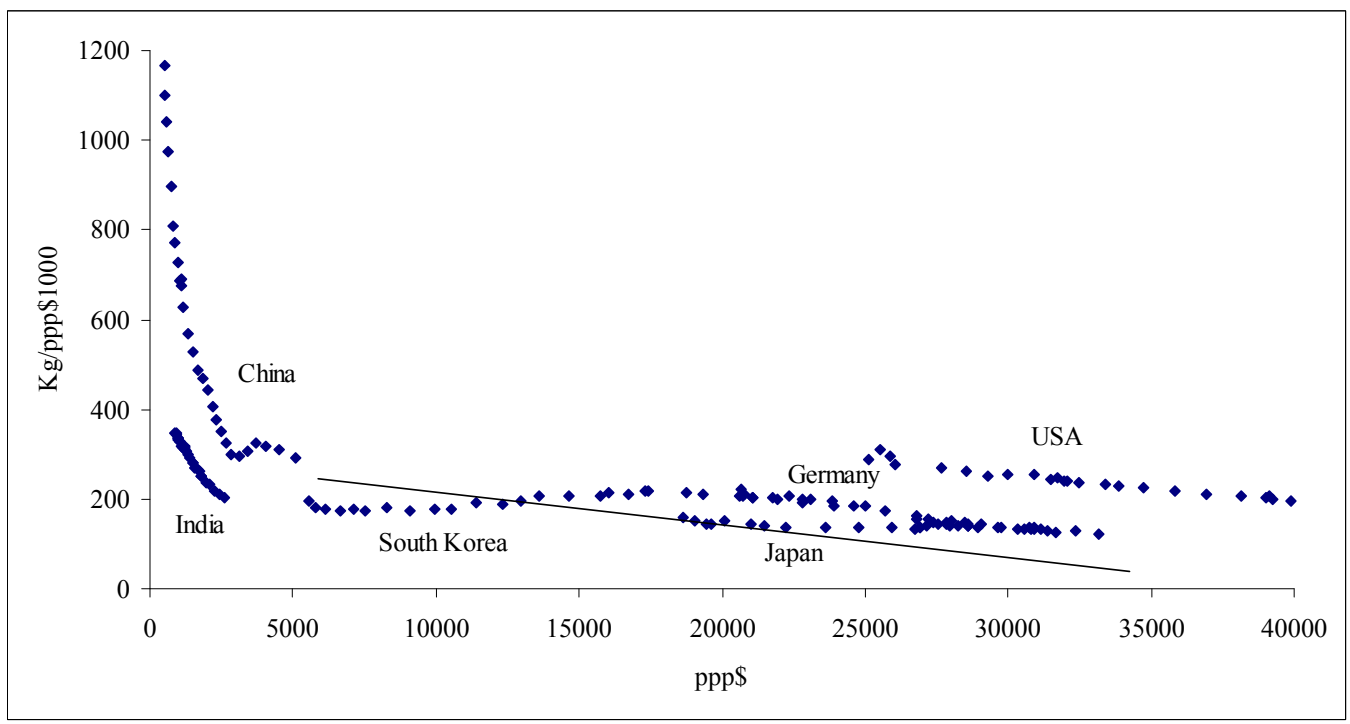

Note: The unit of energy intensity is kilogram of oil equivalent per ppp\$1000 in 2005 constant prices. The data are based on statistics during 1980-2007 for each country.

Source: Author's own calculation using data from the World Bank (2010).

Figure 2 Energy intensity and Economic Development 
To gain a better understanding of the trend in China's energy intensity, the following decomposition approach is considered

$$
I_{t}=C_{t} / Y_{t}=\Sigma_{i} \frac{C_{i t}}{Y_{i t}} \frac{Y_{i t}}{Y_{t}}=\Sigma_{i} E_{i t} S_{i t}=\Sigma_{i} I_{i t}
$$

where $I_{t}, C_{t}$ and $Y_{t}$ represent energy intensity, energy consumption and GDP. The economy is divided into three sectors, namely, the primary, manufacturing and service sectors. ${ }^{1}$ Energy is consumed in the three sectors and for residential purposes $(i=1,2$, 3 and 4). $E_{i t}$ and $S_{i t}$ are employed to measure energy use efficiency and shares of economic activities (or value-added over GDP in the sectors). For the residential sector, value-added is replaced by the value of household consumption.

Equation (1) implies that energy intensity is linked with energy efficiency and sectoral output shares, respectively. This is the so-called index decomposition analysis (IDA) technique proposed and widely used in the literature. Empirically authors have adopted either the Divisia index or the Laspeyres index method. ${ }^{2}$ Several comparative studies however show that the log mean Divisia index (LMDI) method is preferred to other index approaches (Greening et al. 1997, Ang 2004). Following the IDA approach, changes in energy intensity $\left(\Delta I_{t}\right)$ can be decomposed into two components which may be called the efficiency and structural change components, respectively. On the one hand, the efficiency component $\left(\Delta E_{t}\right)$ refers to changes in energy intensity which are associated with changes in energy use efficiency. On the other hand, the

\footnotetext{
${ }^{1} \mathrm{Ma}$ and Stern (2008) presented a more disaggregate decomposition analysis at the national level for the period of 1994-2003.

${ }^{2}$ Ang and Zhang (2000) presented a comprehensive review of the literature, particularly various IDA methods.
} 
structural change component $\left(\Delta S_{t}\right)$ captures the contribution of economic structural changes to energy intensity variation. Symbolically, the additive version can be presented as $^{3}$

$$
\Delta I_{t}=\Delta E_{t}+\Delta S_{t}
$$

where

$$
\begin{aligned}
& \Delta I_{t}=I_{t}-I_{t-1} \\
& \Delta E_{t}=\Sigma_{i} \frac{I_{i t}-I_{i, t-1}}{\ln I_{i t}-\ln I_{i, t-1}} \ln \left(\frac{E_{i t}}{E_{i, t-1}}\right) \\
& \Delta S_{t}=\Sigma_{i} \frac{I_{i t}-I_{i, t-1}}{\ln I_{i t}-\ln I_{i, t-1}} \ln \left(\frac{S_{i t}}{S_{i, t-1}}\right)
\end{aligned}
$$

Following the system of Equations (1) to (5), the year-to-year variations in energy intensity together with the contributions of the efficiency and structural change components are estimated. The 5-year span mean values are presented in Table 2 . The 5-year spans correspond to China's Five Year Plan cycles. According to this table, China's energy intensity declined in most periods during 1981-2007 with the exception of the years of 2001-2005. ${ }^{4}$ The main contributing factor for the decline in energy intensity is efficiency improvement. With the exception of the period of 19811985, structural change has only made marginal contributions to the decline in energy intensity. This phenomenon is clearly demonstrated in the three indexes reflecting the accumulated changes in energy intensity, the efficiency and structural change components over time (see Figure 3). While energy intensity fell substantially between 1980 and 2007, the curve of the structural change index is almost flat. Thus

\footnotetext{
${ }^{3}$ Technical details are available in Ang (2005).

${ }^{4}$ For detailed exploration of the fall and rise of energy intensity in China, the redears may refer to Liao et al. (2007) and Zhao et al. (2010).
} 
economic structural change in China has hardly made any contribution towards the decline in energy intensity for about three decades. This is consistent with the findings in the existing studies using aggregate data (such as Ma and Stern 2008, Liao et al. 2007). It seems that, only during the period of 1981-1985, the Chinese economy maintained continuously a good balance between efficiency improvement and structural changes as far as the trend of energy intensity is concerned. This is worrying for Chinese policy makers who are attempting to steer the economy to an alternative model of development which replies less upon the growth in labourintensive sectors and which emphasizes innovation and growth of the service sector.

Table 2 Energy Intensity Decomposition, 1981-2007

\begin{tabular}{|c|c|c|c|c|c|c|}
\hline & \multicolumn{3}{|c|}{ Changes } & \multicolumn{3}{|c|}{ Shares (\%) } \\
\hline Year & Efficiency & Structure & Intensity & Efficiency & Structure & Intensity \\
\hline $1981-85$ & -12.5 & $-4.8^{\prime}$ & -17.3 & 72 & 28 & 100 \\
\hline $1986-90$ & -6.4 & $-0.9^{\prime}$ & -7.2 & 88 & 12 & 100 \\
\hline $1991-95$ & -9.7 & 2.0 & -7.7 & 127 & -27 & 100 \\
\hline $1996-00$ & -13.9 & -0.2 & -14.0 & 99 & 1 & 100 \\
\hline $2001-05$ & 0.4 & 0.1 & 0.4 & 87 & 13 & 100 \\
\hline 2006 & -5.7 & 1.3 & -4.4 & 131 & -31 & 100 \\
\hline 2007 & -4.1 & -1.0 & -5.1 & 80 & 20 & 100 \\
\hline
\end{tabular}

Sources: Author's own calculation. The raw data are drawn from various issues of China's Energy Statistics Yearbook and China's Statistics Yearbook (NBSC, various issues). 


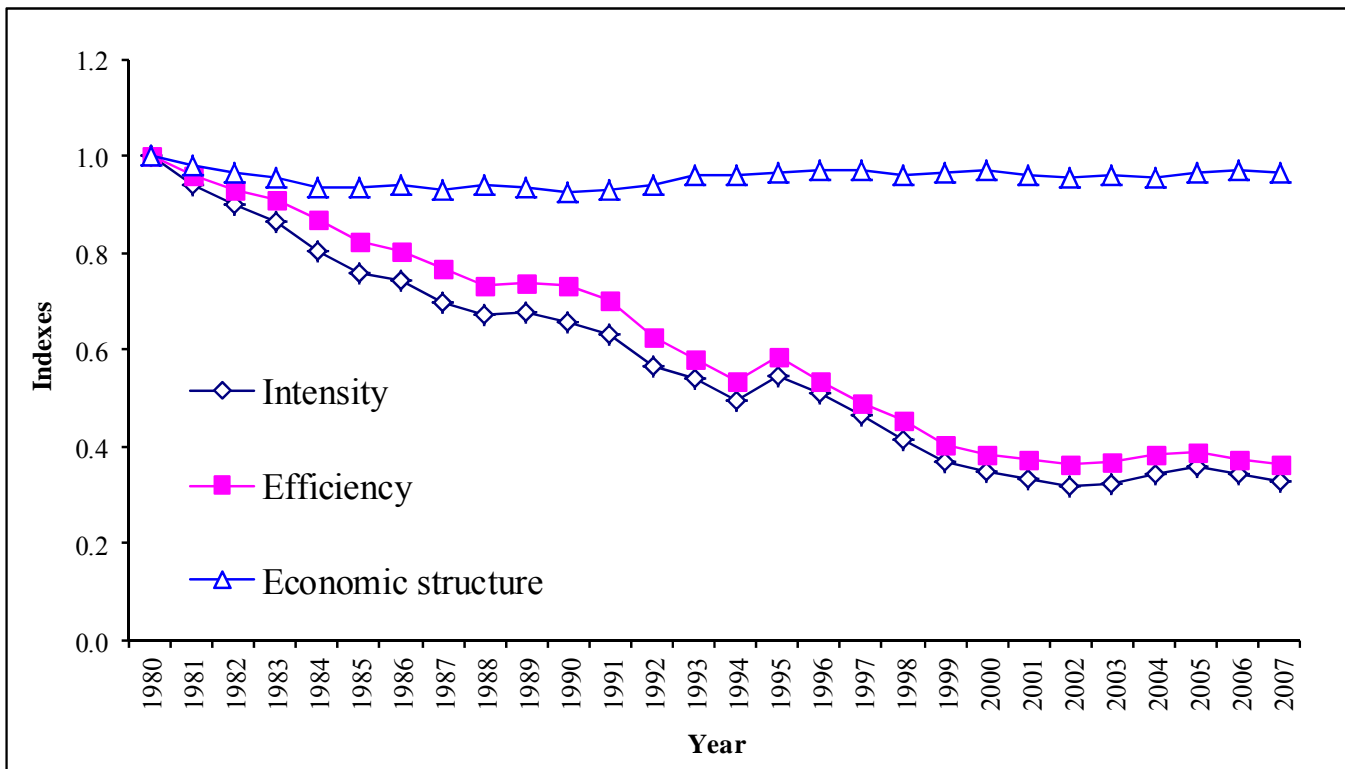

Sources: Author's own calculations. The raw data are drawn from various issues of China's Energy Statistics Yearbook and China's Statistics Yearbook (NBSC, various issues).

Figure 3 Intensity, Efficiency and Structural Indexes, 1980-2007

\section{Energy Intensity in the Regions}

There are few studies focusing on energy intensity in China's regional economies largely due to the scarcity of data. Hu and Wang (2006) and Dan (2007) are two exceptions. Hu and Wang employed the data envelopment analysis (DEA) approach to compare the potential energy consumption with actual energy use in the regions. They divided China geographically into three regions and found that the central region had the lowest average energy efficiency during the period 1995-2002. Dan examined the so-called regional energy efficiency which is defined as the ratio of gross regional product (GRP) per unit of energy use (this is contrary to the conventional energy intensity concept). Dan showed the existence of substantial variations in regional energy efficiency and argued that the coastal regions on average performed better than the rest of the country during 1990-2004. None of them however explored energy intensity at the sector level among the regions. To prepare 
for this paper, a comprehensive database is compiled. The database contains energy consumption information at the sectoral level for twenty-seven Chinese regions during the period of $1997-2007 .^{5}$ As shown in Table 3, there is considerable variation in energy intensity among the regions ranging from around 60 to more than 400 kilogram coal equivalent $(K g C E)$ per 1000 yuan output. ${ }^{6}$ Over time the mean intensity declined from 206 to $149 \mathrm{KgCE}$ per 1000 yuan between 1997 and 2007. So did the standard deviation from 103 to $76 \mathrm{KgCE}$ per 1000 yuan. However, the coefficient of variations remains almost the same being around 0.5 which implies no convergence in regional energy intensity during 1997-2007.

Following the IDA approach described in Section 2, changes in energy intensity in each region is decomposed into two components which reflect the contributions of energy efficiency and economic structural changes, respectively. The decomposition results are presented in Table 3. In general, the western regions were recorded with the highest average energy intensity in 1997 followed in turn by the central and coastal regions. During the decade of 1997-2007, energy intensity fell in 23 regions out of 27 regions considered. In terms of absolute changes, several regions (namely, Beijing, Jilin, Inner Mongolia, Guizhou, Qinghai and Xinjiang) were recorded with a big fall in energy intensity between 1997 and 2007. It is interesting to note that on average the reduction in intensity in the western regions is twice as great as those in the coastal and central regions. Once again it is found that, of the two components, energy efficiency improvement is the dominant contributor to the decline in intensity. In fact, the average contribution of economic structural changes to intensity decline is negative in the three regional groups, that is, the coastal, western and central regions.

\footnotetext{
${ }^{5}$ There are thiry-one administrative regions in mainland China. Due to missing data four regions (Tibet, Hainan, Chongqing and Ningxia) are excluded in this study.

${ }^{6}$ The Chinese currency unit is yuan. In 2010, the exchange rate is approximately 6.6 yuan/US\$.
} 
These regional differences call for further investigation into the determinants of the variation in regional energy intensity.

Table 3 Energy Intensity and Changes between 1997 and 2007

\begin{tabular}{|c|c|c|c|c|c|}
\hline \multirow[t]{2}{*}{ Regions } & \multicolumn{2}{|c|}{ Energy intensity } & \multirow{2}{*}{$\begin{array}{r}\text { Absolute } \\
\text { changes }\end{array}$} & \multicolumn{2}{|c|}{ Component changes } \\
\hline & 1997 & 2007 & & Efficiency & Structure \\
\hline Beijing & 206.4 & 83.6 & -122.7 & -97.3 & -25.4 \\
\hline Tianjin & 187.1 & 94.8 & -92.4 & -96.6 & 4.3 \\
\hline Hebei & 246.8 & 225.5 & -21.3 & -31.1 & 9.9 \\
\hline Liaoning & 310.0 & 284.4 & -25.6 & -32.7 & 7.1 \\
\hline Shanghai & 170.6 & 82.9 & -87.8 & -83.2 & -4.6 \\
\hline Jiangsu & 104.5 & 81.3 & -23.2 & -28.9 & 5.6 \\
\hline Zhejiang & 78.9 & 60.1 & -18.8 & -17.1 & -1.7 \\
\hline Fujian & 59.7 & 80.9 & $\underline{21.3}$ & 15.2 & 6.1 \\
\hline Shandong & 98.2 & 98.6 & $\underline{0.3}$ & -9.8 & 10.1 \\
\hline Guangdong & 81.3 & 62.0 & -19.3 & -22.3 & 3.1 \\
\hline Coastal mean & 154.4 & 115.4 & -39.0 & -40.4 & 1.4 \\
\hline Shanxi & 404.5 & 391.5 & -12.9 & -36.9 & 24.0 \\
\hline Jilin & 328.5 & 167.8 & -160.7 & -183.8 & 23.1 \\
\hline Heilongjiang & 186.9 & 112.3 & -74.6 & -67.5 & -7.2 \\
\hline Anhui & 164.1 & 109.5 & -54.6 & -39.7 & -14.9 \\
\hline Jiangxi & 141.6 & 181.4 & 39.9 & 13.2 & 26.6 \\
\hline Henan & 161.5 & 132.6 & -28.9 & -45.4 & 16.5 \\
\hline Hubei & 170.2 & 124.4 & -45.8 & -34.7 & -11.1 \\
\hline Hunan & 134.9 & 133.9 & -1.0 & -4.6 & 3.6 \\
\hline Central mean & 211.5 & 169.2 & -42.3 & -49.9 & 7.6 \\
\hline InnerMongolia & 435.3 & 224.8 & -210.5 & -261.5 & 51.1 \\
\hline Guangxi & 111.4 & 140.6 & 29.2 & 22.9 & 6.3 \\
\hline Sichuan & 154.6 & 90.0 & -64.5 & -66.5 & 1.9 \\
\hline Guizhou & 384.5 & 226.5 & -157.9 & -175.6 & 17.6 \\
\hline Yunnan & 192.5 & 187.9 & -4.6 & 9.8 & -14.4 \\
\hline Shaanxi & 196.0 & 102.1 & -93.9 & -109.6 & 15.7 \\
\hline Gansu & 271.5 & 184.4 & -87.1 & -91.3 & 4.2 \\
\hline Qinghai & 307.3 & 182.3 & -125.0 & -180.1 & 55.0 \\
\hline Xinjiang & 284.2 & 174.9 & -109.3 & -139.4 & 30.1 \\
\hline Western mean & 259.7 & 168.2 & -91.5 & -110.1 & 18.6 \\
\hline
\end{tabular}

Sources: Author's own calculation. The raw data are drawn from various issues of China's Energy Statistics Yearbook and China's Statistics Yearbook (NBSC, Various issues). 


\section{Determinants of Regional Energy Intensity}

To understand regional variation in energy intensity and its determinants, three regional indices similar to those in Figure 3 are computed using the decomposition results from Section 3. The indices relative to the initial year (1997) capture the trends in energy intensity change and its two components over time. To examine the determinants of regional variation, the indices reflecting the two components, namely, the energy efficiency $\left(E E_{i t}\right)$ component and structural change $\left(S C_{i t}\right)$ component, are regressed against a set of region-specific covariates or explanatory variables $\left(X_{i t}\right)$. Symbolically,

$$
Y_{i t}=\alpha_{0}+\Sigma_{j} \alpha_{j} X_{i j t}+\varepsilon_{i t}
$$

where $Y_{i t}$ represents either the efficiency index $\left(E E_{i t}\right)$ or the structural change index $\left(S C_{i t}\right)$ for region $i$ and at year $t$. The covariates $\left(X_{i j t}\right)$ are selected to capture specific characteristics of regional economies and detailed as follows.

An income (Income) variable is included to reflect the level of economic development in the regions. It is measured by per capita gross regional product (GRP) which is expressed in 2000 constant prices. It is argued that energy efficiency generally improves as an economy develops. ${ }^{7}$ In accordance with this argument, the coefficient of the Income variable is expected to be negative.

\footnotetext{
7 "A Better World for All", a report of the Progress towards the International Development Goals project jointly conducted by the IMF, OECD, United Nations and World Bank, 2000 (http://www.paris21.org/sites/default/files/bwa_e.pdf).
} 
A price (Price) variable is considered to evaluate the impact of fuel prices on energy intensity. As China's fuel price data are not available, the fuel price index for each region is employed as a proxy of fuel prices. It is also expressed in terms of 2000 constant prices. In general, an increase in energy prices raises the cost of production. Producers may respond by improving energy efficiency. Thus the coefficient of the Price variable is expected to be negative.

Other variables considered include the capital-labour ratio (Klratio) and the growth rate of capital stock (Krate). On the one hand, it is argued that energy and technology or capital may be substitutes (Thompson and Taylor 1995, Metcalf 2008). The capitallabour ratio here is employed as a proxy of the level of technology involved. Thus the capital-labour ratio (Klratio) variable may be negatively related to energy intensity. That is, energy intensity is expected to decline as production technology improves. On the other hand, the growth of capital stock may to some extent reflect the speed of old machines and structures being replaced and is hence introduced as a measure of the vintage of capital. New capital may be endowed with energy-saving technology and is thus more energy efficient. Therefore, the coefficient of the Klratio variable is expected to be negative. A time trend (Time) is also included in the model to capture the trend of change over time and is expected to have a negative coefficient.

The baseline model estimated is a fixed effect log-log model. The estimation results are presented in Table 4. The lagged values of some explanatory variables are employed to avoid the problem of simultaneity. Model 1 is the simple version of Equation (6). The estimated coefficients of the Income, Price and Time trend variables have the expected sign and are statistically significant. The coefficients of the capital- 
labour ratio (Klratio) and capital stock growth (Krate) variables have the wrong sign.

To consider the possibility of non-linearity, the squared terms of those variables are added to the model. The estimation results of the optional model (Model 2 in Table 4) confirm the existence of nonlinear relationship as the estimated coefficients of the squared terms are statistically significant. The values of the adjusted $R^{2}$ also indicate that Model 2 is preferred to Model 1 . The $F$ test statistic also shows that the fixed effects are statistically significant. ${ }^{8}$

\footnotetext{
${ }^{8}$ The fixed effect model is also tested against the random effect model. However, for both Models 1 and 2, the Hausman test statistics are collapsed. The estimation results of the random effect model (not reported) do show insignificant coefficients for several explanatory variables.
} 
Table 4 Estimation Results

\begin{tabular}{|c|c|c|c|c|c|c|c|c|}
\hline \multirow[b]{2}{*}{ Variables } & \multicolumn{2}{|c|}{ Model 1} & \multicolumn{2}{|c|}{ Model 2} & \multicolumn{2}{|c|}{ Model 3} & \multicolumn{2}{|c|}{ Model 4} \\
\hline & $\alpha$ & $p$ & $\alpha$ & $p$ & $\alpha$ & $p$ & $\alpha$ & $p$ \\
\hline $\log ($ Income $)$ & -0.433 & 0.001 & -0.304 & 0.015 & 0.151 & 0.000 & 0.157 & 0.000 \\
\hline $\log \left(\right.$ Price $\left._{-1}\right)$ & -0.163 & 0.008 & -0.158 & 0.003 & -0.056 & 0.001 & -0.052 & 0.001 \\
\hline $\log \left(\right.$ Klratio $\left._{-1}\right)$ & 0.566 & 0.000 & 0.562 & 0.000 & 0.039 & 0.215 & 0.032 & 0.333 \\
\hline $\log ^{2}\left(\right.$ KIratio $\left._{-1}\right)$ & & & -0.054 & 0.000 & & & -0.004 & 0.099 \\
\hline $\log \left(\right.$ Krate $\left._{-1}\right)$ & 1.357 & 0.000 & 10.755 & 0.000 & -0.215 & 0.045 & -0.343 & 0.366 \\
\hline $\log ^{2}\left(\right.$ Krate $\left._{-1}\right)$ & & & -38.125 & 0.000 & & & 0.421 & 0.753 \\
\hline Time & -0.027 & 0.004 & -0.055 & 0.000 & -0.009 & 0.004 & -0.010 & 0.011 \\
\hline$F$-value & 27.820 & 0.000 & 35.280 & 0.000 & 30.859 & 0.000 & 27.228 & 0.000 \\
\hline Fixed effect test $(F)$ & 25.349 & 0.000 & 22.849 & 0.000 & 22.397 & 0.000 & 16.194 & 0.000 \\
\hline Adjusted $R^{2}$ & 0.775 & & 0.824 & & 0.793 & & 0.781 & \\
\hline Sample size & 243 & & 243 & & 243 & & 243 & \\
\hline Dependent variable & $\log (E E)$ & & $\log (E E)$ & & $\log (S C)$ & & $\log (S C)$ & \\
\hline
\end{tabular}

Notes: The estimated coefficients of the variables are listed in the $\alpha$ columns and the corresponding $p$-values are printed aside in smaller fonts. 
Several conclusions can be drawn from the estimation results of the fixed effect model. First, energy efficiency improves as income per capita increases among the Chinese regions. Thus, as the regions become more developed, energy use becomes more efficient and hence energy intensity falls. Second, energy price movement is negatively related to energy efficiency. That is, the efficiency component index tends to decline (a positive contribution to intensity decline) as prices increase. The average price elasticity is estimated to be -0.158 . This finding is consistent with the observation by Ma et al. (2009) who showed that energy intensity declined by approximately $20 \%$ during $2000-2004$ due to increasing energy prices. Third, it is confirmed that the efficiency index and capital-labour ratio variable have an inverted U-shaped relationship. However the estimated average turning point is far greater than the actual capital-labour ratios for the Chinese regions. Thus at the current level of development, it seems that there is no substitution effect between capital and energy in China's regional economies. Fourth, the non-linear relationship between the efficiency component index and growth in capital stock or vintage of capital variable shows that technology embodied in new capital may help improve efficiency after growth reaches certain level. The estimated turning point is an average rate of growth of 15.1 per cent. In 2007, seven out of the 27 regions included in the sample surpassed the turning point rate of growth. Thus those regions may have benefited from the speedy replacement of old equipment and structures. Finally, the estimation results show that the efficiency component index tends to fall over time. This is consistent with the positive contribution of the efficiency component to the decline in energy intensity observed in the preceding section. 
For the purpose of comparison, the structural change component index is also regressed against the same set of covariates. The regression results are presented in Table 4 (Models 3 and 4). Apparently Model 3 without the squared terms is preferred to Model 4 in which the two estimated coefficients of the squared terms are statistically insignificant. The estimated coefficients in Model 3 have the expected sign with two exceptions. First, the estimated coefficient of the Income variable in Model 3 is positive and statistically significant. Thus as regional economies grow, structural change has not led to the reduction in energy intensity. On the contrary, it might play the role in raising energy intensity in some regions. This is consistent with the findings from the preliminary analysis. Second, Model 3 also shows a positive relationship between the structural change component index and capital-labour ratio but this relation is statistically insignificant.

\section{Further Considerations}

The analyses in the preceding section are likely affected by several factors. The first factor is the possible existence of unit roots in the variables included in the models. The results of five tests for unit roots are mixed as some tests are statistically significant and others are not (see Table 5). To explore this issue further, the popular generalized method of moments (GMM) is employed to re-estimate the models. In addition, it is assumed that the use of GMM may also correct potential problems with multicollinearity, heteroscedasticity and autocorrelation of unknown forms in the models. Finally, there may be potential problems with endogeneity in the models reported in Table 4. This is another reason to adopt the GMM approach. 
Table 5 Unit Root Test Results

\begin{tabular}{lrrrrr}
\hline Variables & LLC & Breitung & IPS & ADF & PP \\
& & & & & \\
$\log ($ EE $)$ & -7.104 & -0.687 & -0.225 & 63.927 & 81.980 \\
& 0.000 & 0.246 & 0.411 & 0.167 & 0.008 \\
$\log ($ SC $)$ & -5.739 & 2.293 & 0.759 & 40.518 & 60.064 \\
& 0.000 & 0.989 & 0.776 & 0.913 & 0.266 \\
$\log ($ Income $)$ & -20.178 & 0.585 & -4.085 & 162.082 & 44.209 \\
& 0.000 & 0.721 & 0.000 & 0.000 & 0.827 \\
$\log ($ Price $)$ & -16.500 & 0.980 & -3.366 & 142.243 & 180.869 \\
& 0.000 & 0.837 & 0.000 & 0.000 & 0.000 \\
& & & & & \\
$\log ($ Klratio $)$ & -16.108 & -2.463 & -1.941 & 111.487 & 62.114 \\
& 0.000 & 0.007 & 0.026 & 0.000 & 0.210 \\
& & & & & \\
$\log ($ Klratio $)$ & -18.182 & 1.104 & -4.296 & 168.922 & 103.456 \\
& 0.000 & 0.865 & 0.000 & 0.000 & 0.000 \\
& & & & & \\
$\log ^{2}($ Krate $)$ & -5.562 & 1.040 & 0.655 & 47.076 & 132.445 \\
& 0.000 & 0.851 & 0.744 & 0.736 & 0.000 \\
& & & & & \\
$\log ^{2}($ Krate $)$ & -2.601 & 7.864 & 1.256 & 38.012 & 110.487 \\
& 0.005 & 1.000 & 0.896 & 0.951 & 0.000 \\
\hline \multirow{2}{*}{} & & & & &
\end{tabular}

Notes:

The $p$-value is presented underneath each statistic.

LLC: Levin, Lin and Chu $t$ test;

Breitung: Breitung $t$ statistic;

IPS: Im, Pesaran and Shin Wald statistic;

ADF: ADF Fisher $\chi^{2}$ test; and

PP: PP Fisher $\chi^{2}$ test.

Source: Author's own calculation.

The estimation results are illustrated in Table 6 (Models 5 and 6) are estimated using the efficiency component index as the dependent variable. A major issue with the GMM approach is the choice of instrumental variables (IVs) which can lead to overidentification of the model. To deal with this problem, the number of IVs is controlled and the Sargan test is conducted. The IVs used in each model are described in the notes to Table 6. Both models (5 and 6) passed the Sargan test for over-identification. 
To tackle the possible presence of serial correlation, the estimation method built-in in Eviews 7 is employed here. ${ }^{9}$ It is assumed that the errors for a cross-section are heteroscedastic and serially correlated. Under this assumption, the coefficient covariance is calculated and hence the corrected standard errors of the estimated coefficients are reported. The results from the static GMM estimation (Model 5) are generally consistent with those from Model 2 in Table 4.

Table 6 GMM Estimation Results

\begin{tabular}{|c|c|c|c|c|c|c|c|c|}
\hline \multirow[b]{2}{*}{ Variables } & \multicolumn{2}{|c|}{ Model 5} & \multicolumn{2}{|c|}{ Model 6} & \multicolumn{2}{|c|}{ Model 7} & \multicolumn{2}{|c|}{ Model 8} \\
\hline & $:$ & $p$ & $\therefore$ & $p$ & $\therefore$ & $p$ & $\therefore$ & $p$ \\
\hline & & & & & & & & \\
\hline $\log \left(E E_{-1}\right)$ & & & & & 0.310 & 0.000 & & \\
\hline $\log \left(S C_{-1}\right)$ & & & & & & & 0.579 & 0.000 \\
\hline $\log ($ Income $)$ & -0.284 & 0.000 & 0.147 & 0.000 & -0.010 & 0.961 & 0.057 & 0.000 \\
\hline $\log \left(\right.$ Price $\left._{-1}\right)$ & -0.268 & 0.000 & -0.011 & 0.059 & -0.166 & 0.045 & -0.009 & 0.415 \\
\hline $\log \left(\right.$ Klratio $\left._{-1}\right)$ & 0.351 & 0.000 & 0.015 & 0.001 & 0.422 & 0.000 & 0.018 & 0.061 \\
\hline $\log ^{2}\left(\right.$ Klratio $\left._{-1}\right)$ & -0.047 & 0.000 & & & -0.042 & 0.001 & & \\
\hline $\log \left(\right.$ Krate $\left._{-1}\right)$ & 2.857 & 0.004 & 0.226 & 0.000 & 2.795 & 0.049 & 0.165 & 0.000 \\
\hline $\log ^{2}\left(\right.$ Krate $\left._{-1}\right)$ & -8.040 & 0.010 & & & -10.189 & 0.023 & & \\
\hline Time & -0.022 & 0.068 & -0.010 & 0.000 & -0.060 & 0.043 & -0.004 & 0.046 \\
\hline Sargan statistic & 20.340 & 0.729 & 26.527 & 0.489 & 12.613 & 0.943 & 19.352 & 0.681 \\
\hline Sample size & 216 & & 216 & & 216 & & 216 & \\
\hline Dependent variable & $\log (E E)$ & & $\log (S C)$ & & $\log (E E)$ & & $\log (S C)$ & \\
\hline
\end{tabular}

Notes: The estimated coefficients of the variables are listed in the $\alpha$ columns and the corresponding $p$ values are printed aside in smaller font. The IVs used in each model include all independent variables and the dependent variable with lags (from 3 to 5 using the @DYN $(\log (E E),-3,-5)$ command in model 5, @DYN $(\log (S C),-3,-6)$ in model 6, @DYN $(\log (E E),-4,-6)$ in model 7 and @DYN $(\log (S C),-4,-7)$ in model 8. The Time trend variable is untransformed using the @LEV(Time) command. The standard errors of the estimated coefficients are corrected for serial correlation.

The second factor is associated with the inclusion of lagged values. In the preceding sections, while one-period lagged values are used to avoid the potential problem of simultaneity, the lag period could last well beyond one year. For example, a change in energy prices or capital-labour ratios may affect energy intensity (as well as its

\footnotetext{
${ }^{9}$ In Eviews, it is called the "white period method" (Arellano 1987, White 1980).
} 
components) over a few years. To deal with this problem, a partial adjustment model is considered. ${ }^{10}$ This model can be expressed as follows

$$
\begin{aligned}
& Y_{i t}^{*}=\alpha_{0}+\Sigma \alpha_{j} X_{i j t}+\varepsilon_{i t} \\
& Y_{i t}-Y_{i, t-1}=\delta\left(Y_{i t}^{*}-Y_{i, t-1}\right)
\end{aligned}
$$

where $Y_{i t}^{*}$ is the desired efficiency (component) in the $i^{\text {th }}$ region and $t^{\text {th }}$ year and $\delta$ is the coefficient of adjustment. Combining Equations (7) and (8) yields

$$
Y_{i t}=\delta \alpha_{0}+\Sigma_{j} \delta \alpha_{j} X_{i j t}+(1-\delta) Y_{i, t-1}+\delta \varepsilon_{i t}
$$

where $\delta \alpha_{j}$ is the short-run impact of a change in $X$ on $Y$ and $\alpha_{j}$ gives the long-run impacts. Thus the model becomes a dynamic panel data model and can also be estimated using GMM which is now called the dynamic GMM (vs static GMM). The estimation results are reported in Table 6 (Models 7 and 8). For the dynamic GMM estimation, the estimated coefficients of all variables but Income are statistically significant. The estimated adjustment coefficient is $0.69 .{ }^{11}$ Thus the elasticity of 'efficiency' with respect to price is -0.166 in the short run (Model 7) and -.241 in the long run. ${ }^{12}$ These numbers imply that energy price may play a more important role in reducing intensity in the long run.

\footnotetext{
${ }^{10}$ Metcalf (2008) employed the same adjustment process to examine energy intensity and its determinants at the state level in the US.

${ }^{11}$ The adjustment coefficient $\delta=0.69$ is derived using the coefficient $(1-\delta)$ of $\log \left(E E_{-1}\right)$ in Model 7.

${ }^{12}$ The long run price elasticity $(-0.241)$ is the short run elasticity $(-0.166)$ divided by the coefficient of adjustment (0.69).
} 
For the structure models (Models 6 and 8), the results from both static and dynamic GMM estimations are generally consistent with those from the fixed effect estimation, that is, Model 3 in Table 4. Energy price is found to have a negative impact on the structural change component (and hence a positive effect on the reduction of energy intensity) but this effect is not statistically significant. The coefficients of other variables (Income, KLratio and Krate) are also estimated with the wrong sign which is consistent with the decomposition result that structural change component has made little contribution towards the fall in energy intensity among the Chinese regions during 1998-2007.

The last point is however subjected to serious qualification. It should be emphasized that, due to data constraints, the analyses in this paper are highly aggregate and only cover three sectors, agriculture, manufacturing and services. During the sampled period of 1998-2007, structural change might take place within the manufacturing sector in each region. This change cannot be captured in the empirical exercises here and may be partly responsible for the decline in energy intensity and hence efficiency improvement. To shed some light on this issue, Table 7 presents the output shares and energy intensity in China's twenty-eight manufacturing sectors in 1998 and 2007, respectively. Within a decade, energy intensity in the manufacturing sector declined by about two-thirds. If we follow the index decomposition analysis proposed in section 2 , we can show that the decline $(-34.5)$ is purely due to energy efficiency improvement (-37.8) with structural changes having a negative contribution (3.3). This is confirmed in Table 7 which demonstrates that the high energy-intensive sectors (the top 10) all experienced a decline in energy intensity while the changes in output shares are mixed. This is of course based on economy-wide statistics. There 
may be regional variations which call for further investigation when information becomes available.

Table 7 China's Energy Intensity and Output Shares by Sector

\begin{tabular}{|c|c|c|c|c|c|c|}
\hline \multirow[t]{2}{*}{ Sectors } & \multicolumn{3}{|c|}{ Energy intensity } & \multicolumn{3}{|c|}{ Value-added shares } \\
\hline & 1998 & 2007 & Changes & 1998 & 2007 & Changes \\
\hline Smelting and Pressing of Ferrous Metals & 184.8 & 53.0 & -131.7 & 6.5 & 9.7 & 3.1 \\
\hline Raw Chemical Materials and Chemical Products & 142.3 & 37.1 & -105.2 & 7.4 & 7.9 & 0.5 \\
\hline Petroleum Processing and Coking & 139.8 & 42.5 & -97.2 & 3.5 & 3.3 & -0.2 \\
\hline Nonmetal Mineral Products & 135.5 & 42.0 & -93.5 & 6.1 & 5.2 & -0.8 \\
\hline Smelting and Pressing of Nonferrous Metals & 99.1 & 23.9 & -75.2 & 2.2 & 4.8 & 2.6 \\
\hline Chemical Fiber & 77.7 & 19.2 & -58.5 & 1.2 & 0.9 & -0.4 \\
\hline Papermaking and Paper Products & 60.9 & 19.2 & -41.8 & 2.1 & 1.9 & -0.2 \\
\hline Rubber Products & 30.7 & 13.1 & -17.6 & 1.4 & 1.0 & -0.3 \\
\hline Textile Industry & 30.3 & 12.6 & -17.6 & 6.8 & 5.3 & -1.5 \\
\hline Food Production & 30.2 & 7.1 & -23.1 & 2.2 & 2.0 & -0.2 \\
\hline Timber Processing, Palm Fiber and Straw Products etc & 30.1 & 8.0 & -22.1 & 0.8 & 1.1 & 0.4 \\
\hline Food Processing & 26.9 & 5.0 & -21.9 & 4.5 & 5.0 & 0.5 \\
\hline Ordinary Machinery & 22.4 & 5.1 & -17.3 & 4.6 & 5.5 & 0.9 \\
\hline Furniture Manufacturing & 21.1 & 2.3 & -18.8 & 0.5 & 0.7 & 0.2 \\
\hline Metal Products & 20.7 & 9.4 & -11.3 & 3.4 & 3.2 & -0.1 \\
\hline Plastic Products & 19.3 & 7.6 & -11.7 & 2.4 & 2.3 & -0.1 \\
\hline Medical and Pharmaceutical Products & 19.3 & 5.2 & -14.1 & 2.9 & 2.5 & -0.4 \\
\hline Equipment for Special Purposes & 18.3 & 4.7 & -13.6 & 3.2 & 3.3 & 0.1 \\
\hline Beverage Production & 14.2 & 5.2 & -9.0 & 3.6 & 2.0 & -1.6 \\
\hline Transportation Equipment & 14.1 & 3.4 & -10.7 & 7.2 & 7.5 & 0.3 \\
\hline Printing and Record Medium Reproduction & 9.6 & 4.7 & -5.0 & 1.2 & 0.7 & -0.5 \\
\hline Electric Equipment and Machinery & 7.4 & 2.5 & -4.8 & 5.9 & 6.5 & 0.7 \\
\hline Leather, Furs, Down and Related Products & 5.8 & 2.5 & -3.3 & 1.8 & 1.6 & -0.2 \\
\hline Garments and Other Fiber Products & 5.8 & 3.0 & -2.8 & 3.2 & 2.4 & -0.8 \\
\hline Cultural, Educational and Sports Articles & 5.6 & 3.7 & -1.9 & 0.9 & 0.6 & -0.3 \\
\hline Instruments, Meters, Cultural and Office Machinery & 4.9 & 2.2 & -2.7 & 1.1 & 1.3 & 0.1 \\
\hline Electronic and Telecommunications Equipment & 4.4 & 2.5 & -1.9 & 7.5 & 8.5 & 1.1 \\
\hline Tobacco Processing & 2.9 & 0.8 & -2.1 & 5.9 & 3.1 & -2.8 \\
\hline Total & 51.1 & 16.7 & -34.5 & & & \\
\hline
\end{tabular}

Note: Value-added shares are percentage shares. Energy intensity is expressed in kilograms coal equivalent per 1000 yuan.

\section{Conclusion}

To sum up, it is shown in this study that the overall trend of the movement of China's energy intensity in the past decades has been declining. The main driving force for the decline is due to the improvement in energy efficiency while the impact of structural changes in the economy is very limited. There is however substantial variation in 
energy intensity and its trend of changes in Chinese regional economies. In absolute terms, among the 27 regions considered, the highest energy intensity is six or seven times as high as the lowest one. During the period of 1997-2007, the average energy intensity declined. In conformity with the national trend, the decline is mainly due to efficiency improvement with little contribution from economic structural changes. But the changes in energy intensity are very uneven. Some regions experienced a substantial decrease in energy intensity while others were recorded with a modest increase during 1997-2007. Furthermore, it seems that there was no evidence of convergence in regional energy intensity in the past decade.

To understand regional variation in energy intensity, the intensity component indices, namely the efficiency and structural change indices, are regressed against several region-specific covariates. It is found that energy intensity declines as income rises among the regions. Thus China's regional economies generally follow the same dematerialization process as most developed economies have undergone. However "dematerialization" at the current stage of development in China is not due to shifts in manufacturing activities rather it is mainly because of energy efficiency improvement within the sectors. It can be anticipated that China's energy intensity can be reduced further when structural changes become the main driver for dematerialization. For this reason, an optimistic view is that in terms of energy intensity China could even perform better than its East Asian counterparts, Japan and South Korea. It is also found in this study that energy intensity is responsive to energy prices in both the short run and the long run. Thus getting energy prices right is important for reducing energy consumption and hence emissions in China. 
Finally, there is evidence of the existence of nonlinear relationship between energy intensity and capital-labour ratios. However, it seems that all Chinese regions are still on the left hand side of the inverted U-shaped curve. Hence the sample considered does not support the argument that capital and energy are substitutes in China. This study also shows a non-linear relationship between energy intensity and the growth in capital stock or vintage of capital. Some Chinese regions have already passed the turning point of the inverted U-shaped curve. Energy intensity in those regions may be reduced due to the adoption of energy-saving technology embodied in rapidly growing new capital. Thus, while new technology may play a role in improving energy efficiency and hence reducing energy intensity, growth in capital intensity alone would not bring the decline in energy consumption in China, at least in the short run. Other factors such as fuel prices and economic structural changes are also important and should be the focus of economic policies in the coming decades.

\section{References}

Ang, B.W. (2004), "Decomposition Analysis for Policymaking in Energy: Which Is the Preferred Method?", Energy Policy 32(9), 1131-39.

Ang, B.W. (2005), “The LMDI Approach to Decomposition Analysis: A Practical Guide”, Energy Policy 33(7), 867-71.

Ang, B.W. and F.Q. Zhang (2000), “A Survey of Index Decomposition Analysis in Energy and Environmental Studies", Energy 25(12), 1149-76.

Arellano, M. (1987), “Computing Robust Standard Errors for Within-Groups Estimators", Oxford Bulletin of Economics and Statistics 49(4), 431-34.

Bernardini, O. and R. Galli (1993), "Dematerialization: Long Term Trends in the Intensity of Use of Materials and Energy", Futures (May), 431-48. 
Chai, Jian, Ju-E Guo, Shou-Yang Wang and Kin Keung Lai (2009), "Why Does Energy Intensity Fluctuate in China”, Energy Policy 37(12), 5717-31.

Crompton. Paul and Yanrui Wu (2003), “Bayesian Vector Autoregressive Forecasts of Chinese Steel Consumption", Journal of Chinese Economic and Business Studies 1(2), 205-19.

Dan, Shi (2007), “Regional Difference in China's Energy Efficiency and Conservation Potentials", China \& World Economy 15(1), 96-115.

Fisher-Vanden, Karen., Gary H. Jefferson, Hongmei Liu and Quan Tao (2004), “What Is Driving Chinas Decline in Energy Intensity", Resource and Energy Economics 26(1), 77-97.

Garbaccio, R.F., M.S. Ho and D.W. Jorgenson (1999), “Why Has the Energy-output Ratio Fallen in China”, Energy Journal 20(3), 63-91.

Golley, Jane, Dominic Meagher and Xin Meng (2008), “Chinese Urban Household Energy Requirements and CO2 Emissions", in China's Dilemma: Economic Growth, the Environment and Climate Change edited by Ligang Song and Wing Thye Woo, Chapter 16, 334-66, Canberra: ANU E Press \& Asia Pacific Press.

Greening, L.A., W.B. Davis, L. Schipper and M. Khrushch (1997), “Comparison of Six Decomposition Methods: Application to Aggregate Energy Intensity for Manufacturing in 10 OECD Countries”, Energy Economics 19(3), 375-90.

Hu, Jin-Li and Shih-Chuan Wang (2006), “Total-factor Energy Efficiency of Regions in China”, Energy Policy 34(17), 3206-17.

Huang, J.P (1993), "Industry Energy Use and Structural Change: A Case Study of the People's Republic of China", Energy Economics 15(2), 131-36. 
IEA (2009), World Energy Outlook 2009, International Energy Agency (www.iea.org).

Li, G. and S. Wang (2008), "Regional Factor Decompositions in China's Energy Intensity Change: Base on LMDI Technique", Journal of Finance and Economics 34(8), 52-62 (in Chinese).

Liao, Hua, Ying Fan and Yi-Ming Wei (2007), What Induced China's Energy Intensity to Fluctuate: 1997-2006?”, Energy Policy 35(9), 4640-49.

Ma, Chunbo and David I. Stern (2008), “China's Changing Energy Intensity Trend: A Decomposition Analysis”, Energy Economics 30(3), 1037-53.

Ma, Hengyun, L. Oxley and J. Gibson (2009), "Substitution Possibility and Determiants of Energy Intensity for China”, Energy Policy 37(5), 1793-1804.

Metcalf, Gilbert E. (2008), “An Empirical Analysis of Energy Intensity and Its Determinants at the State Level”, The Energy Journal 29(3), 1-26.

NBSC (2010), 2009 Statistical Communiqué of National Economic and Social Development, National Bureau of Statistics of China (www.stats.gov.cn)

NBSC (National Bureau of Statistics of China) (2009), China Statistical Yearbook 2009, Beijing: China Statistics Press.

NBSC (various issues), China Statistical Yearbook, Beijing: China Statistics Press.

Qi, S. and Wei Luo (2007), "Regional Economic Growth and Differences of Energy Intensity in China", Economic Research Journal 7, 74-81 (in Chinese).

Sinton, J. and M. Levine (1994), “Changing Energy Intensity in Chinese Industry: The Relative Importance of Structural Shift and Intensity Change”, Energy Policy 22(3), 239-55.

Thompson, P. and T. Taylor (1995), “The Capital-energy Substitutability Debate: A New Look", The Review of Economics and Statistics 77(3), 565-69. 
Wang, J. and W.Z. Zhong (2009), "The Research of Regional Energy Intensity Difference in China-from the Factor Endowment Perspective", Industrial Economics Research 43(6), 44-51 (in Chinese).

White, H. (1980), “A Heteroskedasticity-Consistent Covariance Matrix Estimator and a Direct Test for Heteroskedasticity”, Econometrica 48(4), 817-38.

World Bank (2001), China: Air, Land, and Water, World Bank, Washington DC.

World Bank (2010), World Development Indicators (Online Database), Washington DC.

Wu, Yanrui (2010), "Regional Environmental Performance and Its Determinants in China”, China \& World Economy 18(3), 73-89.

Yuxiang, Karl and Zhongchang Chen (2009), “Government Expenditure and Energy Intensity in China”, Energy Policy 38(2), 691-94.

Zhang, Z.X. (2003), "Why Did the Energy Intensity Fall in China's Industrial Sector in the 1990s? The Relative Importance of Structural Change and Intensity Change", Energy Economics 25(6), 625-38.

Zhao, X.L., Chunbo Ma and Dongyue Hong (2010), "Why Did China's Energy Intensity Increase during 1998-2006: Decomposition and Policy Analysis”, Energy Policy 38(3), 1379-88.

Zheng, Yingmei, Jianhong Qi and Xiaoliang Chen (2011), “The Effect of Increasing Exports on Industrial Energy Intensity in China”, Energy Policy 39(5), 268898. 
ECONOMICS DISCUSSION PAPERS

2009

\begin{tabular}{|c|c|c|}
\hline $\begin{array}{l}\text { DP } \\
\text { NUMBER }\end{array}$ & AUTHORS & TITLE \\
\hline 09.01 & Le, A.T. & $\begin{array}{l}\text { ENTRY INTO UNIVERSITY: ARE THE CHILDREN OF } \\
\text { IMMIGRANTS DISADVANTAGED? }\end{array}$ \\
\hline 09.02 & Wu, Y. & CHINA'S CAPITAL STOCK SERIES BY REGION AND SECTOR \\
\hline 09.03 & Chen, M.H. & $\begin{array}{l}\text { UNDERSTANDING WORLD COMMODITY PRICES RETURNS, } \\
\text { VOLATILITY AND DIVERSIFACATION }\end{array}$ \\
\hline 09.04 & Velagic, R. & UWA DISCUSSION PAPERS IN ECONOMICS: THE FIRST 650 \\
\hline 09.05 & McLure, M. & $\begin{array}{l}\text { ROYALTIES FOR REGIONS: ACCOUNTABILITY AND } \\
\text { SUSTAINABILITY }\end{array}$ \\
\hline 09.06 & Chen, A. and Groenewold, N. & $\begin{array}{l}\text { REDUCING REGIONAL DISPARITIES IN CHINA: AN } \\
\text { EVALUATION OF ALTERNATIVE POLICIES }\end{array}$ \\
\hline 09.07 & Groenewold, N. and Hagger, A. & $\begin{array}{l}\text { THE REGIONAL ECONOMIC EFFECTS OF IMMIGRATION: } \\
\text { SIMULATION RESULTS FROM A SMALL CGE MODEL. }\end{array}$ \\
\hline 09.08 & Clements, K. and Chen, D. & AFFLUENCE AND FOOD: SIMPLE WAY TO INFER INCOMES \\
\hline 09.09 & Clements, K. and Maesepp, M. & A SELF-REFLECTIVE INVERSE DEMAND SYSTEM \\
\hline 09.10 & Jones, C. & $\begin{array}{l}\text { MEASURING WESTERN AUSTRALIAN HOUSE PRICES: } \\
\text { METHODS AND IMPLICATIONS }\end{array}$ \\
\hline 09.11 & Siddique, M.A.B. & $\begin{array}{l}\text { WESTERN AUSTRALIA-JAPAN MINING CO-OPERATION: AN } \\
\text { HISTORICAL OVERVIEW }\end{array}$ \\
\hline 09.12 & Weber, E.J. & $\begin{array}{l}\text { PRE-INDUSTRIAL BIMETALLISM: THE INDEX COIN } \\
\text { HYPTHESIS }\end{array}$ \\
\hline 09.13 & McLure, M. & $\begin{array}{l}\text { PARETO AND PIGOU ON OPHELIMITY, UTILITY AND } \\
\text { WELFARE: IMPLICATIONS FOR PUBLIC FINANCE }\end{array}$ \\
\hline 09.14 & Weber, E.J. & $\begin{array}{l}\text { WILFRED EDWARD GRAHAM SALTER: THE MERITS OF A } \\
\text { CLASSICAL ECONOMIC EDUCATION }\end{array}$ \\
\hline 09.15 & Tyers, R. and Huang, L. & $\begin{array}{l}\text { COMBATING CHINA'S EXPORT CONTRACTION: FISCAL } \\
\text { EXPANSION OR ACCELERATED INDUSTRIAL REFORM }\end{array}$ \\
\hline 09.16 & $\begin{array}{l}\text { Zweifel, P., Plaff, D. and } \\
\text { Kühn, J. }\end{array}$ & $\begin{array}{l}\text { IS REGULATING THE SOLVENCY OF BANKS COUNTER- } \\
\text { PRODUCTIVE? }\end{array}$ \\
\hline 09.17 & Clements, $\mathrm{K}$. & THE PHD CONFERENCE REACHES ADULTHOOD \\
\hline 09.18 & McLure, $\mathrm{M}$. & $\begin{array}{l}\text { THIRTY YEARS OF ECONOMICS: UWA AND THE WA } \\
\text { BRANCH OF THE ECONOMIC SOCIETY FROM } 1963 \text { TO } 1992\end{array}$ \\
\hline 09.19 & Harris, R.G. and Robertson, P. & $\begin{array}{l}\text { TRADE, WAGES AND SKILL ACCUMULATION IN THE } \\
\text { EMERGING GIANTS }\end{array}$ \\
\hline 09.20 & $\begin{array}{l}\text { Peng, J., Cui, J., Qin, F. and } \\
\text { Groenewold, N. }\end{array}$ & STOCK PRICES AND THE MACRO ECONOMY IN CHINA \\
\hline 09.21 & Chen, A. and Groenewold, N. & $\begin{array}{l}\text { REGIONAL EQUALITY AND NATIONAL DEVELOPMENT IN } \\
\text { CHINA: IS THERE A TRADE-OFF? }\end{array}$ \\
\hline
\end{tabular}




\begin{tabular}{|c|c|c|}
\hline \multicolumn{3}{|c|}{$\begin{array}{l}\text { ECONOMICS DISCUSSION PAPERS } \\
2010\end{array}$} \\
\hline $\begin{array}{l}\text { DP } \\
\text { NUMBER }\end{array}$ & AUTHORS & TITLE \\
\hline 10.01 & Hendry, D.F. & $\begin{array}{l}\text { RESEARCH AND THE ACADEMIC: A TALE OF } \\
\text { TWO CULTURES }\end{array}$ \\
\hline 10.02 & McLure, M., Turkington, D. and Weber, E.J. & A CONVERSATION WITH ARNOLD ZELLNER \\
\hline 10.03 & $\begin{array}{l}\text { Butler, D.J., Burbank, V.K. and } \\
\text { Chisholm, J.S. }\end{array}$ & $\begin{array}{l}\text { THE FRAMES BEHIND THE GAMES: PLAYER'S } \\
\text { PERCEPTIONS OF PRISONER'S DILEMMA, } \\
\text { CHICKEN, DICTATOR, AND ULTIMATUM GAMES }\end{array}$ \\
\hline 10.04 & Harris, R.G., Robertson, P.E. and Xu, J.Y. & $\begin{array}{l}\text { THE INTERNATIONAL EFFECTS OF CHINA'S } \\
\text { GROWTH, TRADE AND EDUCATION BOOMS }\end{array}$ \\
\hline 10.05 & Clements, K.W., Mongey, S. and Si, J. & $\begin{array}{l}\text { THE DYNAMICS OF NEW RESOURCE PROJECTS } \\
\text { A PROGRESS REPORT }\end{array}$ \\
\hline 10.06 & Costello, G., Fraser, P. and Groenewold, N. & $\begin{array}{l}\text { HOUSE PRICES, NON-FUNDAMENTAL } \\
\text { COMPONENTS AND INTERSTATE SPILLOVERS: } \\
\text { THE AUSTRALIAN EXPERIENCE }\end{array}$ \\
\hline 10.07 & Clements, $\mathrm{K}$. & $\begin{array}{l}\text { REPORT OF THE } 2009 \text { PHD CONFERENCE IN } \\
\text { ECONOMICS AND BUSINESS }\end{array}$ \\
\hline 10.08 & Robertson, P.E. & $\begin{array}{l}\text { INVESTMENT LED GROWTH IN INDIA: HINDU } \\
\text { FACT OR MYTHOLOGY? }\end{array}$ \\
\hline 10.09 & Fu, D., Wu, Y. and Tang, Y. & $\begin{array}{l}\text { THE EFFECTS OF OWNERSHIP STRUCTURE AND } \\
\text { INDUSTRY CHARACTERISTICS ON EXPORT } \\
\text { PERFORMANCE }\end{array}$ \\
\hline 10.10 & Wu, Y. & $\begin{array}{l}\text { INNOVATION AND ECONOMIC GROWTH IN } \\
\text { CHINA }\end{array}$ \\
\hline 10.11 & Stephens, B.J. & $\begin{array}{l}\text { THE DETERMINANTS OF LABOUR FORCE } \\
\text { STATUS AMONG INDIGENOUS AUSTRALIANS }\end{array}$ \\
\hline 10.12 & Davies, M. & $\begin{array}{l}\text { FINANCING THE BURRA BURRA MINES, SOUTH } \\
\text { AUSTRALIA: LIQUIDITY PROBLEMS AND } \\
\text { RESOLUTIONS }\end{array}$ \\
\hline 10.13 & Tyers, R. and Zhang, Y. & APPRECIATING THE RENMINBI \\
\hline 10.14 & Clements, K.W., Lan, Y. and Seah, S.P. & $\begin{array}{l}\text { THE BIG MAC INDEX TWO DECADES ON } \\
\text { AN EVALUATION OF BURGERNOMICS }\end{array}$ \\
\hline 10.15 & Robertson, P.E. and Xu, J.Y. & $\begin{array}{l}\text { IN CHINA'S WAKE: } \\
\text { HAS ASIA GAINED FROM CHINA'S GROWTH? }\end{array}$ \\
\hline 10.16 & Clements, K.W. and Izan, H.Y. & $\begin{array}{l}\text { THE PAY PARITY MATRIX: A TOOL FOR } \\
\text { ANALYSING THE STRUCTURE OF PAY }\end{array}$ \\
\hline 10.17 & Gao, G. & WORLD FOOD DEMAND \\
\hline 10.18 & $\mathrm{Wu}, \mathrm{Y}$. & $\begin{array}{l}\text { INDIGENOUS INNOVATION IN CHINA: } \\
\text { IMPLICATIONS FOR SUSTAINABLE GROWTH }\end{array}$ \\
\hline 10.19 & Robertson, P.E. & DECIPHERING THE HINDU GROWTH EPIC \\
\hline 10.20 & Stevens, G. & $\begin{array}{l}\text { RESERVE BANK OF AUSTRALIA-THE ROLE OF } \\
\text { FINANCE }\end{array}$ \\
\hline 10.21 & Widmer, P.K., Zweifel, P. and Farsi, M. & $\begin{array}{l}\text { ACCOUNTING FOR HETEROGENEITY IN THE } \\
\text { MEASUREMENT OF HOSPITAL PERFORMANCE }\end{array}$ \\
\hline
\end{tabular}




\begin{tabular}{|l|l|l|}
\hline 10.22 & McLure, $\mathrm{M}$. & $\begin{array}{l}\text { ASSESSMENTS OF A. C. PIGOU'S FELLOWSHIP } \\
\text { THESES }\end{array}$ \\
\hline 10.23 & Poon, A.R. & $\begin{array}{l}\text { THE ECONOMICS OF NONLINEAR PRICING: } \\
\text { EVIDENCE FROM AIRFARES AND GROCERY } \\
\text { PRICES }\end{array}$ \\
\hline 10.24 & Halperin, D. & $\begin{array}{l}\text { FORECASTING METALS RETURNS: A BAYESIAN } \\
\text { DECISION THEORETIC APPROACH }\end{array}$ \\
\hline 10.25 & Clements, K.W. and Si. J. & $\begin{array}{l}\text { THE INVESTMENT PROJECT PIPELINE: COST } \\
\text { ESCALATION, LEAD-TIME, SUCCESS, FAILURE } \\
\text { AND SPEED }\end{array}$ \\
\hline 10.26 & Chen, A., Groenewold, N. and Hagger, A.J. & $\begin{array}{l}\text { THE REGIONAL ECONOMIC EFFECTS OF A } \\
\text { REDUCTION IN CARBON EMISSIONS }\end{array}$ \\
\hline 10.27 & $\begin{array}{l}\text { Siddique, A., Selvanathan, E.A. and } \\
\text { Selvanathan, S. }\end{array}$ & $\begin{array}{l}\text { REMITTANCES AND ECONOMIC GROWTH: } \\
\text { EMPIRICAL EVIDENCE FROM BANGLADESH, } \\
\text { INDIA AND SRI LANKA }\end{array}$ \\
\hline
\end{tabular}




\section{ECONOMICS DISCUSSION PAPERS}

2011

\begin{tabular}{|c|c|c|}
\hline $\begin{array}{l}\text { DP } \\
\text { NUMBER }\end{array}$ & AUTHORS & TITLE \\
\hline 11.01 & Robertson, P.E. & $\begin{array}{l}\text { DEEP IMPACT: CHINA AND THE WORLD } \\
\text { ECONOMY }\end{array}$ \\
\hline 11.02 & Kang, C. and Lee, S.H. & $\begin{array}{l}\text { BEING KNOWLEDGEABLE OR SOCIABLE? } \\
\text { DIFFERENCES IN RELATIVE IMPORTANCE OF } \\
\text { COGNITIVE AND NON-COGNITIVE SKILLS }\end{array}$ \\
\hline 11.03 & Turkington, D. & DIFFERENT CONCEPTS OF MATRIX CALCULUS \\
\hline 11.04 & Golley, J. and Tyers, R. & $\begin{array}{l}\text { CONTRASTING GIANTS: DEMOGRAPHIC CHANGE } \\
\text { AND ECONOMIC PERFORMANCE IN CHINA AND } \\
\text { INDIA }\end{array}$ \\
\hline 11.05 & Collins, J., Baer, B. and Weber, E.J. & $\begin{array}{l}\text { ECONOMIC GROWTH AND EVOLUTION: } \\
\text { PARENTAL PREFERENCE FOR QUALITY AND } \\
\text { QUANTITY OF OFFSPRING }\end{array}$ \\
\hline 11.06 & Turkington, D. & $\begin{array}{l}\text { ON THE DIFFERENTIATION OF THE LOG } \\
\text { LIKELIHOOD FUNCTION USING MATRIX } \\
\text { CALCULUS }\end{array}$ \\
\hline 11.07 & Groenewold, N. and Paterson, J.E.H. & $\begin{array}{l}\text { STOCK PRICES AND EXCHANGE RATES IN } \\
\text { AUSTRALIA: ARE COMMODITY PRICES THE } \\
\text { MISSING LINK? }\end{array}$ \\
\hline 11.08 & Chen, A. and Groenewold, N. & $\begin{array}{l}\text { REDUCING REGIONAL DISPARITIES IN CHINA: IS } \\
\text { INVESTMENT ALLOCATION POLICY EFFECTIVE? }\end{array}$ \\
\hline 11.09 & Williams, A., Birch, E. and Hancock, P. & $\begin{array}{l}\text { THE IMPACT OF ON-LINE LECTURE RECORDINGS } \\
\text { ON STUDENT PERFORMANCE }\end{array}$ \\
\hline 11.10 & Pawley, J. and Weber, E.J. & $\begin{array}{l}\text { INVESTMENT AND TECHNICAL PROGRESS IN THE } \\
\text { G7 COUNTRIES AND AUSTRALIA }\end{array}$ \\
\hline 11.11 & Tyers, R. & $\begin{array}{l}\text { AN ELEMENTAL MACROECONOMIC MODEL FOR } \\
\text { APPLIED ANALYSIS AT UNDERGRADUATE LEVEL }\end{array}$ \\
\hline 11.12 & Clements, K.W. and Gao, G. & QUALITY, QUANTITY, SPENDING AND PRICES \\
\hline 11.13 & Tyers, R. and Zhang, Y. & $\begin{array}{l}\text { JAPAN'S ECONOMIC RECOVERY: INSIGHTS FROM } \\
\text { MULTI-REGION DYNAMICS }\end{array}$ \\
\hline 11.14 & McLure, M. & A. C. PIGOU'S REJECTION OF PARETO'S LAW \\
\hline 11.15 & Kristoffersen, I. & $\begin{array}{l}\text { THE SUBJECTIVE WELLBEING SCALE: HOW } \\
\text { REASONABLE IS THE CARDINALITY } \\
\text { ASSUMPTION? }\end{array}$ \\
\hline 11.16 & Clements, K.W., Izan, H.Y. and Lan, Y. & VOLATILITY AND STOCK PRICE INDEXES \\
\hline 11.17 & Parkinson, $\mathrm{M}$. & $\begin{array}{l}\text { SHANN MEMORIAL LECTURE 2011: SUSTAINABLE } \\
\text { WELLBEING - AN ECONOMIC FUTURE FOR } \\
\text { AUSTRALIA }\end{array}$ \\
\hline 11.18 & Chen, A. and Groenewold, N. & $\begin{array}{l}\text { THE NATIONAL AND REGIONAL EFFECTS OF } \\
\text { FISCAL DECENTRALISATION IN CHINA }\end{array}$ \\
\hline 11.19 & Tyers, R. and Corbett, J. & $\begin{array}{l}\text { JAPAN'S ECONOMIC SLOWDOWN AND ITS } \\
\text { GLOBAL IMPLICATIONS: A REVIEW OF THE } \\
\text { ECONOMIC MODELLING }\end{array}$ \\
\hline 11.20 & $\mathrm{Wu}, \mathrm{Y}$. & $\begin{array}{l}\text { GAS MARKET INTEGRATION: GLOBAL TRENDS } \\
\text { AND IMPLICATIONS FOR THE EAS REGION }\end{array}$ \\
\hline
\end{tabular}




\begin{tabular}{|l|l|l|}
\hline 11.21 & Fu, D., Wu, Y. and Tang, Y. & $\begin{array}{l}\text { DOES INNOVATION MATTER FOR CHINESE HIGH- } \\
\text { TECH EXPORTS? A FIRM-LEVEL ANALYSIS }\end{array}$ \\
\hline 11.22 & Fu, D. and Wu, Y. & $\begin{array}{l}\text { EXPORT WAGE PREMIUM IN CHINA'S } \\
\text { MANUFACTURING SECTOR: A FIRM LEVEL } \\
\text { ANALYSIS }\end{array}$ \\
\hline 11.23 & Li, B. and Zhang, J. & $\begin{array}{l}\text { SUBSIDIES IN AN ECONOMY WITH ENDOGENOUS } \\
\text { CYCLES OVER NEOCLASSICAL INVESTMENT AND } \\
\text { NEO-SCHUMPETERIAN INNOVATION REGIMES }\end{array}$ \\
\hline 11.24 & Krey, B., Widmer, P.K. and Zweifel, P. & $\begin{array}{l}\text { EFFICIENT PROVISION OF ELECTRICITY FOR THE } \\
\text { UNITED STATES AND SWITZERLAND }\end{array}$ \\
\hline 11.25 & Wu, Y. & $\begin{array}{l}\text { ENERGY INTENSITY AND ITS DETERMINANTS IN } \\
\text { CHINA'S REGIONAL ECONOMIES }\end{array}$ \\
\hline & & \\
\hline
\end{tabular}

